\title{
SPEECH FROM THE MARGIN: GERTRUDE STEIN'S TENDER BUTTONS AND AGÁTA GORDON'S KECSKERÚZS
}

\author{
EDIT ZSADÁNYI \\ Eötvös Loránd University, Budapest, \\ Hungary
}

The various feminist projects converge on the idea that language (constructed in its largest sense, as the varied system of discourses through which the world becomes constructed) is the primary cultural agency through which the masculine dominates and represses the feminine. To effect a change at all, it is necessary to undermine language from within, or to mark the ways in which language reveals its own undermining. In much feminist thought, language is understood as a wholly phallogocentric and monolithic domain, which has no place for the "woman" who becomes in her difference and otherness the figure for all that remains repressed and silenced. ${ }^{1}$ I am analyzing two works by women writers that foreground the issues of marginality and textuality. They belong to different literary traditions: Gertrude Stein's Tender Buttons to the American modernist, and Agáta Gordon's Kecskerúzs to the contemporary Hungarian literary context. The reason I read them together is that they both address the problem of identity as it is constructed by discourse. Also, they are exemplary works of an experimentalist feminine literary discourse that has a long tradition in the nineteenth and twentieth centuries. As Friedman and Fuchs summarize:

\footnotetext{
Although the woman in the text may be the particular woman writer, in the case of twentieth-century women experimental writers, the woman in the text is also an effect of the textual practice of breaking patriarchal fictional forms; the radical forms - nonlinear, nonhierarchical, and decentering - are, in themselves, a way of writing the feminine. In subverting traditional modes of narrative, writers from Gertrude Stein, Dorothy Richardson, and Virginia Woolf to Christine Brooke-Rose, Eva Figes, and Kathy Acker have been undermining the patriarchal assumptions that inform these narrative modes ... In exploding dominant forms, women experimental writers not only assail the social structure, but also produce an alternate fictional space, a space in which the feminine, marginalized in traditional fiction and patriarchal culture, can be expressed. ${ }^{2}$
}

Hungarian Studies 15/1 (2001)

0236-6568/2001/\$5.00 @ 2001 Akadémiai Kiadó, Budapest 
Thus, one of the most important characteristics of women's experimental writing is that a certain marginal and feminine speaking position is accompanied by the radical questioning of traditional literary forms. The focus of my interest in this paper is the relation between experimentalist textual devices and the marginal, feminine speaking position.

Tender Buttons is often considered to be a pure language play that departs from familiar conventions and celebrates the free play of writing. It is not easy to decide weather we should read it as poetry or as prose. Agáta Gordon's work also stays somewhere between poetry and fiction since most of its chapters start with a poem that introduces the following narrative. The narrative parts are dissected into paragraphs that have no punctuation. The semantics of the sentences are basically recognizable but the syntax is ambiguous most of the time. Tender Buttons is often interpreted as expressing female points of view, mainly those of lesbianism. Kecskerúzs clearly raises the issues of homosexuality, for the narrator is a lesbian woman who speaks about the hardships of her love affairs. The main similarity I am interested in is the joint appearance of marginality (as theme and as speaking position) and experimental literary language. I am looking for an answer to the question of what happens to the reader when he or she is faced with the close connection between language games and lesbian points of view. Analyzing recent essays on Gertrude Stein's Tender Buttons, I will focus on the problem of the narrative of reading. I intend to illustrate that these underlying narratives naturalize and assimilate the strangeness and otherness of the work. I will argue that while experiencing the position of the other during the reading and interpreting process, the reader, in both cases, may realize the otherness within him or herself that challenges the notion of the reader as a coherent and stable identity.

Gertrude Stein's experimental language plays had been considered unreadable, or meaningless, for a long time. A reassessing of Stein's work has been developed throughout the 1980s and 1990s. Employing a number of critical perspectives poststructuralist, feminist, psychoanalytic - this contemporary renaissance in Stein criticism has opened multiple new configurations of meaning in her works. It is definitely the merit of recent Stein criticism that it made Stein's critique of representation available for contemporary readers. In other words, by offering coherent interpretations, critics made Stein's texts accessible and readable. I am interested in the underlying contradiction of these readings, namely, how is it possible to interpret a text that obviously challenges the reader's interpretative strategies. 


\section{Play on Words and Play with the Reader: Gertrude Stein's Tender Buttons}

From Three Lives to Tender Buttons Gertrude Stein created a series of texts that engage, relatively early and in a radical faction, what we have come to recognize as the most critical issue of modernist art - the problem of representation. Three Lives was her first major assault on the conventions governing literary representation in the nineteenth century. This text gradually came to be regarded as a central force in reshaping the tradition of American fiction in the twentieth century. Long before Three Lives received recognition, Stein had gone on to invent far more radical ways of manipulating language. Tender Buttons enacts the principles of fragmentation and difference and celebrates the free play of writing as a combinative game limited only by systematic laws of language. The more radically a literally text departs from familiar conventions, the more actively the reader must struggle to determine how to read it; and many readers have simply declared Stein's works meaningless." 3

Tender Buttons describes a female world of domestic objects and rituals - of dresses, hats, tables and curtains, mealtimes and bedtimes, cleanliness, and dirt. The iconography of domestic life dominates the text. But in its artful rearrangement of these details, the text models a world in which objects, foods, and rooms are liberated from their normal subordination to human routines and purposes. ${ }^{4}$ According to Walker, the particular pleasure that Tender Buttons provides is this kind of artful reordering of the familiar world. Beginning with Cézanne's and Picasso's still lives, modernist artists have revealed the strangeness of familiar objets. Duchamps's famous exhibition of the urinal inaugurated a new fascination with "found objets", removed from their normal contexts and habituating functions. Oppenheims's fur cup and, more recently Oldenburg's fans and other "soft" re-creations of manufactured objects transgress the order of everyday experience more violently, by transforming these domestic objects into bizarre artifacts that totally violate the functionality of cups and fans. Stein's objects cannot be seen or touched. But concrete nouns and adjectives call things to mind, and syntax can bind them together in startling new combinations ${ }^{5}$

Ellen E. Berry, in her study on Stein, Curved Thought and Textual Wandering: Gertrude Stein's Postmodernism (1992) raises many of the questions informing my project here. Reviewing recent feminist interpretations of Stein, Berry identifies two narratives of reading among them. The one implies the narrative of the struggle against the Father. This assessment recounts the tale of the woman writer's struggle against internal and external patriarchal censors. In this scenario of reading Stein's texts are anti-authoritarian, inscribing her sometimes playful, often painful, efforts to transgress phallocentric norms, logic and structures. The other narrative of reading follows an escape scenario: Stein's texts escape from 
the law of the Father [to an intersubjective] space of perfect mutuality. Stein's texts permit and affirm a kind of writing (l'écriture feminine, women's writing or experimental writing) in which the artist unmakes patriarchal structure by inscribing an other-than-Oedipal measure of desire. As readers, we play blissfully with her texts and wander through the text instead of controlling and mastering it. ${ }^{6}$

Berry points at a dichotomy inherent in the feminist narratives of confrontation and escape. She claims that these narratives of reading prevent us from acknowledging the pains and desires evoked in the reader and the difference of the other woman with whom we are engaged in our textual dialogue. "Stein's works remind us that we cannot always know the other's desire and that we may not always speak for or with the other woman whom we see in order to explain from a feminist perspective." She argues for a reading perspective that moves beyond the above narratives. Stein's "unreadable" texts "help to suggest the necessity for and the difficulty of moving beyond the oppositions implicit in the feminist narratives of confrontation and escape. Such a movement is necessary in order to seek more subtle and inclusive theories of reading capable of taking into account nonoppositional differences among women." mits that such a movement is difficult, partly because narrative is a persistent and powerful mode of structuration that tends to retextualize itself in critical practices and institutional discourses. Difficult, also, because these feminist narratives of the reading process are enabling narratives that have grown out of real necessities. $^{9}$

Narrative, indeed, is a powerful frame and concept of literary approaches. For instance, when criticizing narratives of reading, Berry immediately repeats another scenario, another pervasive narrative of scholarly discourses, the narrative of always moving beyond others' theories. On the one hand, I do agree that Tender Buttons challenges our categorization system and our basic concepts - the concepts of narrative are included in this radical questioning process. On the other hand, I would be hesitant to make such a definite statement that we should move beyond the narratives of reading.

First, because by adding more narratives of reading to the present ones, one might be able to extend the restrictions and limitations inherent in narrative concepts. It seems also important to define narrative when one uses the term narrative of reading. As is well known, narrative is a highly contested concept. Not only does it have several definitions within narrative theories but also it is a widely employed concept in several contexts such as history writing, psychology, political theory and cognitive theories. It seems though that Berry means a certain plot, a scenario that tells the story of confrontation or escape from the Law of the Father. Jonathan Culler uses the term story when he talks about narratives of reading: "reading is divided and heterogeneous, useful as a point of reference only when composed into a story, when constructed or construed as a narrative." 
Culler's concept of the stories of reading is different from the former one; it stays on a more abstract level. One could summarize his notion in the following way: stories of reading tell us what happens to the reader during the reading process. Culler distinguishes several stories of reading: for instance, Wolfgang Iser tells of the reader actively filling in gaps, actualizing what the text leaves indeterminate. Stanley Fish tells a more dramatic story. His story of manipulation is full of dramatic encounters, moments of deception and surprises, which portray reading as a process of discovery. The result for the reader after an unsettling experience could be as well a self-conscious understanding of the process by which we construct meaning. ${ }^{10}$ The outcome of such reading, summarizes Culler, is always knowledge. These stories follow an innocent reader, confident in traditional assumptions about structure and meaning, who encounters the deviousness of texts, falls into traps, is frustrated and dismayed, but emerges wiser for the loss of illusions." 11 Reading Stein's frustrating and exciting play on words, a basic question was raised for me: is it really knowledge that we gain from the literary encounter with the text? The stories of reading can be of course further discussed. Let me just finally refer to Teresa de Lauretis' comments on the nature of narrative logic that is of importance to my study. "All narrative, in its movement forward toward resolution and backward to an initial moment, a paradise lost, is overlaid with ... an oedipal logic." 12 According to de Lauretis, narrative works to authorize and legitimize the male status of the subject, whose desire for illumination cannot be distinguished from his desire for stable identity. ${ }^{13}$ Put it in another way, any narrative (including narrative of reading, I suppose) that moves toward revelation, in other words, towards knowledge, reestablishes the reader's identity as a coherent subject. The quoted narratives of reading are strongly based on a formalist concept of narrative in which a self-identical subject discovers the world, or the world of the text. The reader in these stories of reading is a coherent, united subject, a Cartesian ego. It seems that the notion of narrative of reading cannot be distinguished from a self-identical reading subject. The concept of the stories of reading relays on the concept of narrative as logical structuration, and not on those concepts that emphasize the discursive characteristics of narrative. Narratives of reading (even feminist ones) indeed become problematic in the case of Tender Buttons. The work refuses to give us any revelation, any sort of knowledge. Therefore, it undermines the concept of narrative as well as the reader's coherent subjectivity.

Since the most striking peculiarity of Tender Buttons is that it refuses to offer any decipherable meaning, I take this refusal as a poetic function that makes problematic the reader's customary activities such as meaning-making, categorization, and imposing order on distinct features. In other words, the text defends itself from "approaching" in the very literal sense of the word, and forces the reader to reevaluate his or her own concept of understanding the text. 
Categorization as a basic form of conceptualization is called into question in several ways. The reader is urged to face the problem of how to make categories with clear definitions and clear boundaries. Titles, for instance, are often misleading, which undermines the custom of naming a thing and then describing it. The passage under the title $A D O G$ talks about a "little monkey that goes like donkey" (26). The $S A L A D$ turns to be a winning cake (57).

Tender Buttons undermines the categorization system as such. The first two chapters (Objects and Food) are definitely written in nominal style: categories of things and categories of abstract entities. The names or the categories make sense, but they refuse any intention of the reader to impose a system, or an order on them. The unfunctionality of the system reveals the problematic nature of categorization as a system.

In the first two chapters of Tender Buttons the reader sees nothing else but categories. Under the name of an object comes a text that looks like a description. Usually a few paragraphs, or sometimes a few lines. The typographic outlook raises the expectation that the text is a description, then it violates immediately the reader's desire to find a clear definition. The texts are usually nicely cut into pieces and paragraphs. The reader looks into the empty container of the category and does not find in it what he or she is looking for.

Similarly, we look into the third chapter (Rooms), we look into the room, but this place seems empty. This chapter talks about the room itself, as a frame or as a 'table' in the Foucaultean sense: "a table where for instance the umbrella encounters the sewing machine, and also a table, a tabula, that enables thought to operate upon the entities of our world, to put them in order, to divide them into classes ... the table upon which, since the beginning of time language, has intersected space." 14

The closing section, Rooms seems to be a coherent prose fiction at first sight. The title is followed by paragraphs that seem to be connected to each other. Of course, it is far from a coherent narrative; still the reader has the impression that one way or another it tells a story. Rooms recalls some typical conventions of a traditional narrative: a chronological order for instance can be clearly followed. It starts somewhere in a mythical past when basic distinctions and basic discrimination came into being. An elementary event had happened that has - according to the passionate and sometimes even furious tone of the speech - outrageous consequences for the present. "Act so that there is no use in a center. A wide action is not a width. A preparation is given to the ones preparing. They do not eat who mention silver and sweet. There was an occupation." The tenses of the verbs follow this chronological order. In the first part of the chapter, the verb form is mostly past tense, and later on it turns to be present tense. Also, Rooms employs characteristic narrative phrases, such as: to begin, it was done, and then there was, the 
truth has come, it happened in a way, the conclusion came, the time came when, then came the time for. Therefore, the work recalls and challenges the concept of narrative at the same time.

We may recognize a fragmented story about a distinguishing and discriminative act, but it comes to the surface only in random moments. Most of the time it is a free play of signifier that characterizes the text. And these tendencies are connected with another one: subversive and displacing references to gender categories: "the sister was not a mister," or "replacing a casual acquaintance with an ordinary daughter does not make a sun," or "Then there is a way of earning a living. Who is a man."

It follows that the critique of logocentrism that occurs throughout the whole text is connected in Stein's view with the critique of stable sexual identities. This invites the reader to realize the relation between the discursive practice of metaphysics and uniform sexual identities. Stein's characteristic language and language plays are in accordance with Judith Butler's argument that western metaphysics requires a compulsory heterosexual order that retains gender as a substance and as a self-identical being. In a binary framework, compulsory heterosexuality constitutes coherence or unity of either gender: man or woman. Thus the critique of stable sexual identities implies a critique of western metaphysics. ${ }^{15}$ As Nicola Pitchford in a recent article emphasizes: Stein's critique of representation presents a standard modernist view: the text is about the process of cognition itself. What may be unusual is that Stein presents cognitive process as dependent on a gendered set of binary structures embedded in language. In Tender Buttons an alternative emerges to the heterosexual binary contract on which representation is founded. Therefore, the lesbian desire, which is often identified among the interpretations of Tender Buttons, may be as much about a strategy of representation as about actual physical sexuality. ${ }^{16}$

We have the idea that we are listening to a story but it is not clear at all what it is about. The voice of this story is sometimes passionate, sometimes cynical or playful using paradoxical or tautological phrases. As if a foreign speaker would try hard to explain something to us. We are carefully listening, are engaged in communicative situation, and sometimes are getting to grasp some meaning sometimes we are completely lost and frustrated, but we can as well be fascinated by the play on words. We are in an in-between comprehending situation, somewhere between understanding and not understanding the text. Still, the communication and the reading process continue.

The reader stays in an in-between situation and is becoming uncertain about his/herself. Who can be this "I" who read the text? As the text provides no revelation, just partial understanding, it follows that it does not provide and does not reassure any stabilization of identity. On the contrary, communication with the 
strangeness and unknowable part of the text draws the reader into a situation in which a person has to realize the difference within his/herself, one has to recognize the unknown parts of his or herself.

\section{Chiastic Structures Involving the Reader: Agáta Gordon's Kecskerúzs}

The characters' situations in Kecskerúzs are marginal in many senses. They are students and young intellectuals with no prospects for any promotion. Typical objects and behavioral patterns of the 1980s can be traced in the text that seeks to reactivate the Hungarian reader's historical and personal experiences rooted in the depressive atmosphere of the last days of communism. We see students in rented flats, two-three of them sharing the same room, the dismal surroundings of the student's hostels, the living and working conditions of young professionals, the clumsy official management, and the like. The characters are dependent on the political regime to such an extent that they are hardly able or willing to realize this dependence. They are homeless in their own country in several senses of the word. Leona (the first person storyteller) and Izolda are a lesbian couple, which has to go through long and humiliating procedures to be able to live together. Izolda, who was born into the Hungarian minority somewhere outside of Hungary, needs to marry Leona's friend Lala. A Hungarian reader exactly understands the situation; at that time there was no other way possible to move to Hungary. Izolda moves from "home to home," as the novel puts it. The duplication of the notion of home, which is normally mentioned in singular form, creates a displacement. One who needs to move from home to home might as well be considered as a homeless person. The unusual expression "from home to home" also displaces the original meaning of the word. Home as a final reference disappears in a similar way as the final signified disappears in a derridean concept of language. And language is a crucial issue in this resettlement theme of the novel because one of the main reasons one decides to move from Hungarians to Hungarians is the language itself.

The awkward situation of lesbian love and fake marriage with a man form a series of lies that slowly poison the protagonists' lives. The main characters' private lives are emphasized all the time, and the main reasons for the difficulties are marginalized by the storyteller. They are mentioned casually as irrelevant facts. The expression "human rights," for instance, is hidden even in the following minor remark of the text:

A ránk kényszerített szituáció kínozni kezdett mindannyiunkat és akármelyik szálát kezdtük kibogozni már mind a négyünkön elszorított fojtogatott felhorzsolt vagy megbénított valamit de tehetetlen- 
ségünkben sem gondoltunk az emberi jogokra eszünkbe sem jutott annyira nem is voltak Izoldának és nekem sem. ${ }^{17}$

Homelessness and marginality may be interpreted in further senses. Leona hides Izolda for more than a year in her one-room apartment, which is provided to her by her employer. Then they move to a deserted place, to a small house in the woods, which is thirty minutes walking distance from a small village. Leona and Izolda's story is framed by another narrative that takes place in a mental hospital. Leona tells her love story to a psychiatrist, called Orsolya Hostell, who offers Leona shelter, saves and cures her. But as the name indicates, the shelter is just a hostel, an institute where the patients' complaints are aired and receive a sympathetic ear; and Orsolya Hostell is not a person who is able to offer Leona a home. Homecoming, or arriving to any final reconciliation, never occurs in the novel. The continuous atmosphere of exile may be related to the language of the work. The sentences never end; instead they just run on into each other. Furthermore, the poems and the narrative chapters refer to each other in that way that they provide no clear connection.

There is hardly any sign in the text that refers to a direct speech by a character. The characters never speak in a straightforward manner about their lesbian feelings. The reader is informed about it in indirect ways. For instance, other characters talk about their suspicion, or in other cases the storyteller turns to another sense, seeing. Visual effects are often included in these descriptions of homosexuality:

Egyszer aztán világossá vált minden de annyira hogy be kellett csuknom a szemem és utána még hónapokig lehunyva tartottam feltünés nélkül az órákon és a tanulóban lehajtott fejjel mintha olvasnék és alvást szimuláltam jármúveken és minden szabad percben mert vakított a felismerés még sokáig ostrom alatt tartott szüntelen képzelgésekkel egy Sarolta-arcú lényről de nem akartam hogy nyitott szemeimben felismerje őt valaki rajtam kívül (32).

In the following quotation we can recognize an exchange between different organs of sensation. It is not speech and silence that are opposed to each other but seeing and silence.

\footnotetext{
hiába faggattam az arcokat most kellett megtudnom ebben az ázsiában egy télifürdőben hogy otthon az orrom előtt szereti egymást két lány akik Emese szerint kétségtelenül nyíltan és tudatosan leszbikusok mert Emese nem tételezte fel hogy amit ő olyan világosan lát azt pont az érintettek nem és nem akarják komolyan venni és magukra szabadítani hanem elássák és rémülten és gyomorfájósan hallgatják még évekig a nyüszítését (52). (my emphasis)
} 
A relevant passage regarding the sense of seeing and focalization occurs later on in the novel. Orsolya Hostell and Leona analyze a poem that talks about the speaker's memory of his or her grandmother. Leona would like to follow the psychiatrist's thoughts, but all of a sudden, as an involuntary memory, images of her own childhood come to her mind. She sees herself in her adolescence.

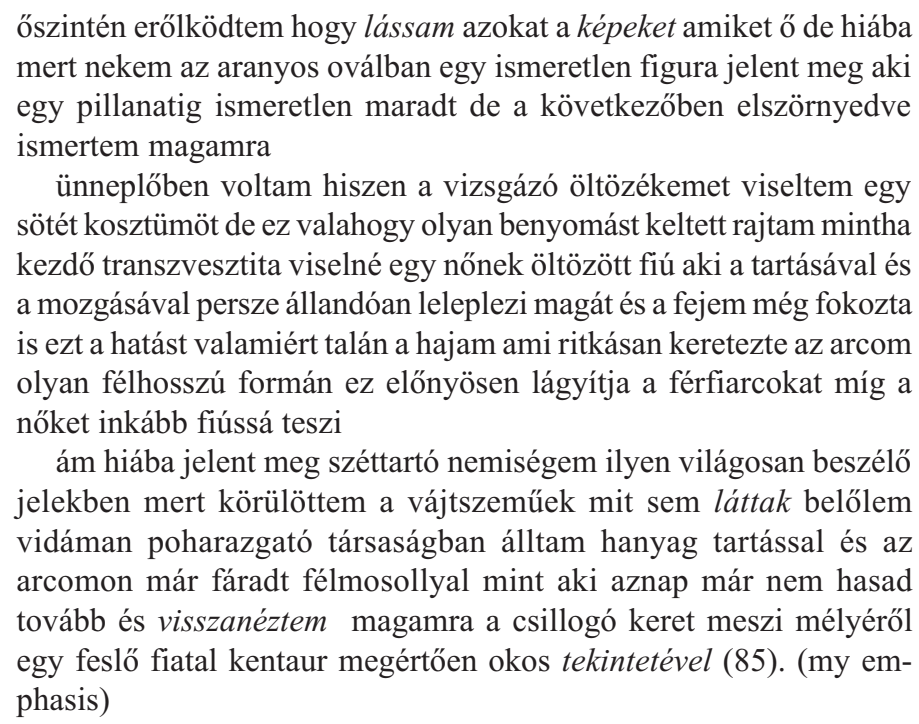

Leona, the narrator, makes an effort to see what the doctor means but instead she sees something else, her own earlier self. We look through a double focalization, and see how she views herself. In her view, a family event emerges about which she gives a detailed and perceptive description. In this visual narration a family photo with a young woman at the center, a kind of still life, appears in front of our eyes. The woman looks back to the viewer and to the reader as well. We are faced with an unstable and insecure homosexual adolescence. The picture is not clear, it is disturbed by the interference of the double focalization. Not only do we see this figure through multiple perspectives; it is exactly these perspectives that constitute the figure. The reader cannot exclude him or herself from the multiplicity of perspectives. Moreover, as the figure from the picture looks back to us, readers, we see ourselves as we are reflected in her eyes. In this view, we cannot have a clear picture of ourselves, either. The reflecting gaze undermines the reader's clear focalization and clear image of oneself. The instability of the figure that stands lonely on the family photo destabilizes the reader's fixed identity.

The language of the novel is a lyrical and rhythmical prose language. The short chapters are usually introduced by poems that are related to the following narrative. As mentioned earlier, the chapters are divided into paragraphs that are not distributed further into sentences. One may follow a vague sentence structure, but 
the text often disturbs the reader's sense about the borders of the sentences. The new information, an adjective or an adverb, is connected to the earlier words in a way that we do not know exactly if it is additional information or already a new sentence. In other words, certain phrases can belong to the former and to the following clause at the same time. An A-B structure turns to be a B-A or B-C structure, which may be seen as a chiastic figure. Rhetorically speaking, chiasmus is an inversion in the second phrase of order followed in first, or any structure in which elements are repeated in reverse, giving the pattern ABBA. Usually the repeated elements are specific words, and the syntactic frames holding them (phrases, clauses) are parallel in construction, but may not necessarily be so. Chiasmus may be manifested on any level of the text or (often) on multiple levels at once: phonological (sound patterning), lexical or morphological, syntactic (phrase or clause construction) or semantic/thematic. Chiasmus can also be seen as an envelope pattern, as one form of inversion within repetition. Others define it as the crisscross placing of sentence members that correspond in either syntax or meaning, with or without verbal repetition. ${ }^{18}$ The last two concepts of chiasmus, or chiasmus in a wider sense, may apply fairly to the present novel. Chiastic syntactic constructions are such typical and ubiquitous figures of Kecskerúzs that they occur on almost every page. Let us see a few random examples!

így hát széttártam a kezeimet ezt azonnal és hálásan beleegyezésként értelmezte Hostell felállt és rögtön intézni kezdte a formaságokat nekem pedig ott kellett várnom a teljesen jellegtelen szobácskában ahol ezután minden nap eltöltöttem egy-két órát vele de most még zavarban voltam (13-14). (my emphasis)

Hostell may belong both to the former (értelmezte) and also to the latter word (felállt).

görnyedten ültem a kényelmetlenül mélyre süppedö fotelban nem dőltem hátra hanem az újságokat néztem az asztal alatti polcon (14). (my emphasis)

A kényelmetlenül mélyre süppedö fotelban can be the ending of the first or the beginning of the second sentence.

a nagy napon amikor némi késéssel befutott Izolda sebesvonata és rohanvást értünk albérleti szobáinkba átöltözni déli egy órakor már mind a négyen ünneplősen és izgatottan toporogtunk a házasságkötő terem művészbejárójánál (98). (my emphasis)

Similarly, déli egy órakor adverbal clause can be the part of two different sentences. More precisely, the sentences follow each other so quickly that they pile up (accumulate) upon each other. The excitement of the speaker is clearly sug- 
gested by the technique in which it is hard to tell the events as fast as they happened. Beside chiasmus, insertion is the most frequent rhetorical strategy. The speaker inserts new information into the sentence and then returns to the old one. Chiastic structures are recognizable in many different senses. In fact, the figure of chiasmus is changing all the time, and it returns in different configurations. The continuous transformation of the figure, the metamorphoses itself becomes an omnipresent meta-figure of the text that enacts the way that chiasmus functions.

Chiasmus and insertion prevent the linear reading process. The reader is forced all the time to look and see back and forth in the process of making sense of the sentences. In the case of chiasmus it is even possible to constitute two different sentences, and we cannot decide which is the correct one. Therefore, undecidability immediately comes into play. The criss-cross figure of chiasmus is closely related to the metaphor of woods, that is a recurring trope of Kecskerúzs. It seems significant that on the cover of the book we see woods with leaves and bushes in a closeup focalization. When progressing in the text, one might have the strange feeling that one is walking in the woods. As we step back and forth and see which phrase belongs to which clause, it is like bending the branches and the bushes in front of us in order to be able to move ahead. During this process, "walking in the woods" as a figure of reading emerges to us. The reading experience is like walking alert in an unknown forest and watching every step carefully. The concept of woods gains special significance as we come across it in different senses and in different contexts throughout the novel. In some cases it means a refuge from the culture that leaves no room for any alternative life. Leona and Izolda live together in the woods far from the controlling eyes of civilization. Izolda likes walking in the forest with her dogs like the goddess Artemis, and these strolls provide a mythological backdrop for the events. Interestingly, the novel ends with this motif. The dogs lacerate small animals in the forest. Most of the scenes of the introductory poems refer to wild nature with trees, bushes, wind, and birds. The metaphoric of the poems often relay on this semantic field. The first word of the last poem is "Erdo" (woods) and that stands alone in the first line. One may consider it as the title of the last poem. Woods, on the other hand, are also conceptualized as an intimidating and fearsome entity. After Izolda's leaving, Leona feels as if the woods move toward her:

csak annyi történt hogy közelebb jött és fenyegetőbb lett ami kinn volt eddig és nehezebben és mélyebbre kellett magamba húzódnom hogy védett helyet találjak.

When talking about the hopeless relation with Izolda, Leona uses the metaphor "woods." This is the place where she lost her way, from where the doctor may lead her out: 
nagyon csodálkoztam azon is hogy mély apátiámba milyen rövidke idő elmúltával belopódzott az új kapcsolódás izgalma és vezetett kifelé az erdőből ahová Izoldával tévedtünk.

In the final chapter the characters leave the woods behind them. After climbing a hill, a grand view and a wide perspective open up before them. For Leona and Emese it also means an opening of a new relationship. The reader also gets out of the bushes and branches of the text and almost arrives at a reconcilable solution. But on the very last pages the narrator and main character Leona changes her mind and walks back into the woods. This time Izolda's murderous greyhounds accompany her. The novel ends at this point and the reader may wonder if he or she could really find the way out of the forest of the text.

The relationships among the four characters, Emese, Lala, Izolda and Leona form a chiastic configuration. Lala marries Izolda, but Izolda lives in a love relationship with Leona. Emese is friend with Leona, but at the end of the novel she steps into Izolda's place. Though Lala married Izolda just because of the political situation, he falls in love with her, and thus assumes Leona's position for a while. The relationship of these four characters can be mapped on the four shanks of the letter chi, X (the basic figure of chiasmus). The people next to each other, Lala and Izolda, Izolda and Leona, Leona and Emese have love relations with each other; the people, who stay at the opposite sides of the shanks of the letter X, Lala and Leona, Izolda and Emese form friendships.

Izolda and Leona befriend with another lesbian couple, Gerle and Paloma, who live in the neighborhood. They visit each other, stay overnight from time to time, and another love affair appears among them. The four persons, Izolda, Leona, Gerle and Paloma formulate an exact chiastic figure as they lay on a bed next to each other.
semmivel sem lett volna könnyebb ha Gerle bevallja léhaságát és elmeséli hogy a nagyon széles kihúzható ágyon ahol ő aludt belül Izoldával talán félreérthetô meghittséggel suttogtak egymás között és nem is a simogatásoktól volt mégiscsak csalás az a néhány éjszaka amikor mi olyan mélyen és ártatlanul aludtunk az ágy két szélén Palomával hanem attól hogy mind a ketten ráismertek ebben a kezdetben egy korábbira ami pedig még nem fejeződött be de hagyták mégis hogy megszülessen kettejük között amit aztán el kellett ásniuk mint egy kutyakölyköt (160).

The figure of chiasmus as a replacement between characters seems another significant version that involves the figure of the reader as well. The interchange between the characters can be illustrated by the following example. találjak

mélyebbre kellett magamba húzódnom, hogy védett helyet 


\begin{abstract}
többnyire találtam is csak üreset és valahogy sivárat mert senkit se tudtam beköltöztetni senkinek a szeretetét vagy érdeklődését amely közönsége lett volna magányomnak csak Izoldáét és túl pontosan tudtam hogy ez nem igaz mert igazi beszélgetések már régóta csak az elmémben zajlottak vele ahová betelepítettem távol lévő lényét aki végre beszélt hozzám és más szemmel nézett rám mint én magamra (164).
\end{abstract}

Izolda, the beloved person (third person singular) becomes an imaginary second person figure who speaks and looks at the speaker. The narrator (Leona) speaks from the position of an "I". In Izolda's gaze she recognizes a self that is different from her own view of herself. Paradoxically, in this remote perspective the "I" becomes a she, the familiar and self-identical figure becomes a more distinct one, yet it seems more acceptable and closer to the speaker's notion of herself. The play of identity goes on in the following passages:

valószínűleg túl nyílt és elővigyázatlan gesztus tőled egy ilyen mosolyféle több mint amennyit adni szeretnél - magyarázta elégedetten titkos belső Izoldám és ez elgondolkodtatott

nem örültem neki hogy már megint nyitott könyv vagyok és néhány gyakorlatba kezdtem a fürdőszobai tükrök előtt hogy kifejezéstelen legyen az arcom még véletlenül se kiismerhetetlen hanem egyszerüen csak bamba amin a primitív érzések is csak hosszú reakcióidővel láthatódnak félénken és tétovázva (165).

An actual mirror is involved in the play that further multiplies the dichotomy of the "I and you" structure. The multiplicity of perspectives invites the reader to look into the mirror, in other words, to participate in this confusing yet playful game. In the end, it is hard to answer the simple question: who is who? The clause "nyitott könyv vagyok" (I am an open book) functions, perhaps, as a mise-enabyme narrative device, a mirror in the represented room in which the reader can recognize himself or herself. More correctly, the reader is urged to face the fact that even his or her own self cannot be formulated as a coherent self-identical figure. The idiom "open book" in this context undermines another established distinction: the distinction between the literal and the figurative. The figurative meaning is displaced here and the literal becomes foregrounded. We have literally a book in our hand that makes fun of us. In a manner similar to Tender Buttons, the text reflects on us. Not only do we read the text but it also it reads us. 


\section{Conclusion}

The omnipresence of the figure chiasmus in Kecskerizs, just as the radically subversive language games of Stein, invites the reader to participate in a constantly transforming textual play. At the end we become totally uncertain of what the difference is between otherness and identity. While getting involved in the undecidability of textuality, one step by step challenges the notion of the reader as a united and fixed identity.

During the reading process we listen to the otherness of the text that makes us realize the otherness of ourselves. We would like to read the text and approach it, but instead, the text speaks back; and it is the text that reads us. Instead of a revealing narrative of reading, Stein's Tender Buttons and Gordon's Kecskerúzs offer us another figure of reading, which is a self-subversive, a self-questioning act. Not only do we see diverse characters but we also see our diversity in the reflection of their eyes. The otherness of these texts may be taken into consideration only in that case when the reader recognizes the difference within him or herself. As a result, another figure of reading appears, it is not a narrative of reading, but the figure of self-dividedness as a way to communicate with the difference of the other.

\section{Notes}

1. Elaine Showalter, Lea Baecher, and Walton A. Litz (eds), Modern American Women Writers (New York: Macmillan, 1991), 336.

2. Ellen G. Friedman and Miriam Fuchs, "Contexts and Continuities: An Introduction to Women's Experimental Fiction," in: Breaking the Sequence: Women's Experimental Fiction, ed. Ellen G. Friedman and Miriam Fuchs (Princeton: Princeton University Press, 1989), 3-4.

3. Harriet Scott Chessman, The Public Is Invited to Dance: Representation, the Body, and Dialogue in Gertrude Stein (Stanford: Stanford University Press, 1989), 1.

4. Jayne L. Walker, The Making of a Modernist: Gertrude Stein from Three Lives to Tender Buttons (Amherst: University of Massachusetts Press, 1986), 127.

5. Ibid., 128.

6. Ellen E. Berry, Curved Thought and Textual Wandering: Gertrude Stein's Postmodernism (Ann Arbor: The University of Michigan Press, 1992), 12-15.

7. Ibid., 34.

8. Ibid., 34 .

9. Ibid., 34 .

10. Jonathan Culler, On Deconstruction: Theory and Criticism after Structuralism (Ithaca: Cornell University Press, 1982), 69-77.

11. Ibid., 79.

12. Teresa de Lauretis, Alice Doesn't: Feminism, Semiotics, Cinema (Bloomington: Indiana University Press, 1984), 121. 
13. Ibid., 125

14. Michael Foucault, The Order of Things: An Archeology of the Human Sciences (New York: Random House, 1994), xvii.

15. Judith Butler, Gender Trouble: Feminism and the Subversion of Identity. (New York: Routledge, 1990), 6-7.

16. Nicola Pitchfold, "Unlikely Postmodernism: Stein's Tender Buttons" American Literary History (1999/4): 646-648.

17. Agáta Gordon, Kecskerúzs (Budapest: Magvető, 1997).

18. The New Princeton Encyclopedia of Poetry and Poetics. (Princeton: Princeton University Press, 1993), 183-184. 